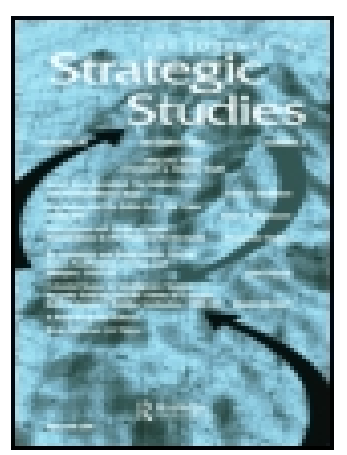

The Journal of Strategic Studies

\title{
Strategic nuclear missiles in Turkey: The Jupiter affair, 1959-1963
}

\section{Nur Bilge Criss}

To cite this article: Nur Bilge Criss (1997) Strategic nuclear missiles in Turkey: The Jupiter affair, 1959-1963, The Journal of Strategic Studies, 20:3, 97-122, DOI: 10.1080/01402399708437689

To link to this article: https://doi.org/10.1080/01402399708437689

曲 Published online: 24 Jan 2008.

Submit your article to this journal ๘

Џll Article views: 724

4 Citing articles: 2 View citing articles 진 


\title{
Strategic Nuclear Missiles in Turkey: The Jupiter Affair, 1959-1963
}

\author{
NUR BİLGE CRISS
}

Debates about the Cold War continue to flourish as more original data become available for research.' Among these debates the Cuban Missile Crisis is of particular interest not least because it was probably the most dangerous among other crises of the Cold War period. The Crisis had further implications. First, the idea of deploying US strategic missiles in other NATO countries was abandoned. Second, the Crisis adversely affected the relationship of both the United States and the Soviet Union with Turkey and Cuba in regard to future commitments to the security of their respective allies. ${ }^{2}$ Third, historiography recently shifted from the image of President John F. Kennedy, who would not bargain with the Soviets, even when confronted with nuclear war, to the image of a Kennedy, who was courageous enough to do so. ${ }^{3}$ The 'bargain' was to remove the Jupiter IRBMs from Turkey in return for the removal of Soviet missiles from Cuba. Further, Kennedy pledged not to invade Cuba. Since both promises had been verbal, conducted by secret diplomacy through the US Attorney General Robert Kennedy and the Soviet Ambassador to Washington DC, Anatolii Fyodorovich Dobrynin, plausible bargains remained the subject of speculation. The mere suggestion of a bargain was vehemently denied by both the US and Turkish authorities alike. ${ }^{4}$ When a rumor began to circulate in Turkey during the mid-1960s of a trade off (presumably instigated by the Soviet Embassy in Ankara) the leftists believed it wholeheartedly and the rightist establishment continued to deny it but were however embarrassed. Accordingly, another implication of the Crisis was that it effected a polarization in Turkish domestic politics, albeit as one factor among many. The final, but not the least important implication of the Crisis is to do with the nature of alliances in regard to why and how alliance cohesion may break down.

The purpose of this study is to assess why Turkey had been enthusiastic about deploying the Jupiters at all; the nature of Turkish-American relations in this process; the decision-making mechanism within Turkey's ultraconservative democracy of the time; and the diplomatic, domestic implications of the strategic nuclear weapons deployment and their 
subsequent removal in 1963. This is also a study of how perceptions of threat become more real than life itself. In this case, if one of the serious perceptions was the Soviet threat to Turkey, the other one was a fear of losing US economic aid in the event of a rapprochement between the superpowers.

\section{The Politico-Strategic Debate}

The Turkish government's decision to deploy IRBMs in 1959 has been subject to much political controversy yet to little academic debate within the country from the viewpoints of strategy, Turkish-US relations, and the nature of decision-making at the time. However, neither the incumbent government of the Democratic Party, nor the opposition, the Republican People's Party, or the National Unity Committee, which facilitated the coup d'état of 1960, questioned the actual deployment of nuclear missiles on Turkish territory. The ruling elite perceived the presence of Jupiters as a natural part of Turkey's commitment to NATO. This indicated that Turkish foreign and defense policies would adhere to the status quo despite domestic changes. Whenever reference was made to the Jupiters in the press, the missiles were described as rockets, or guided missiles and usually the Çiğli base was alluded to as the rocket base. The word 'nuclear' was rarely mentioned, thereby removing the stigma attached to it. Yet to possess strategic nuclear weapons also seemed prestigious, a factor which was perceived to increase a member country's intra-alliance status.

Distaste and a fear of communism on the part of the Turkish government was coupled with a fear of encirclement in the light of the leftist coup in Iraq. The Menderes government consistently ignored friendly overtures from the Soviets and deliberately held back from establishing closer economic relations with them. The Prime Minister was thoroughly convinced that economic ties with the northern neighbor would automatically result in a Soviet leverage to re-direct Turkish foreign policy. Although it is one factor among many in the decision to deploy IRBMs it was recognised that economic dependence on the US would also bring Turkey as close as possible to being a nuclear target originating from the USSR. But, the American dimension of economic dependence and its implications was not questioned by Menderes in the 'all white' or 'all black' atmosphere of the Cold War, which did not leave any room for shades in distinguishing between risk and security.

Turkey was trying to pursue an active foreign policy in the Middle East, as a regional actor which promoted Western (namely US and British) policies. Its membership in the ill-fated Baghdad Pact of 1955, had by 1959 , opened the legal route for the US and Turkey to conclude bilateral 
agreements. The US was not an official member of the Pact, but made separate bilateral agreements of cooperation with Iran, Turkey and Pakistan. The 'Agreement of Cooperation Between the Government of the United States of America and the Government of the Republic of Turkey' was signed in Ankara on 5 March 1959, and entered into force the same day. The two governments affirmed their right to cooperate for security and defense.

Considering that under article 1 of the Pact of Mutual Cooperation signed at Baghdad on February 24, 1955, the parties signatory thereto agreed to cooperate for their security and defense, and that, similarly, as stated in the above-mentioned Declaration, the Government of the United States of America, in the interest of world peace, agreed to cooperate with the governments making that Declaration for their security and defense; Recalling that, in the above-mentioned Declaration, the members of the Pact of Mutual Cooperation making that Declaration affirmed their determination to maintain their collective security and to resist aggression direct or indirect. ${ }^{3}$

It is on this legal basis that Turkey signed a note on 18 September 1959, agreeing to the deployment of Jupiter (SM-78) missiles on its territory, under the general banner of an 'Agreement Relating to the Introduction of Modern Weapons into NATO Defense Forces in Turkey'. 6 One observer noted that the agreement was presented to the Turkish Grand National Assembly on 26 October $1959 .^{7}$ But, the minutes of meetings of the Turkish Grand National Assembly do not reveal that a parliamentary meeting was held on 26 October 1959, unless of course the cabinet was notified of the Agreement on introducing modern weapons at a closed session. The bilateral agreement pertaining specifically to missile deployment was not to be made public and that it entered into force on 28 October 1959, after ratification in the US, attests to the secrecy surrounding the Jupiter missiles.

In fact, there were no domestic impediments politically or legally to such a decision-making process in Turkey. The opposition was not taken into account by the government, and there were no socialist or communist parties to question the decision. It is plausible that İsmet İnönü (the leader of the opposition Republican People's Party, a hero of the Turkish War of Independence, and second President of the Republic who meticulously kept Turkey out of World War II) would have objected to the deployment of Jupiters in Turkey had the issue been open to debate. Inönü did not object to deployment after it was announced publicly, probably because he realized that it was already too late, and may not have wished to project the image that he was against Turkey's possession of 'modern' weapons.

There were no legal impediments in the way of the government either. The 1924 Turkish Constitution was amended on 20 May 1959, allowing the 
government to sign and execute (at the time of signing) international agreements with the US and EC countries. ${ }^{8}$ That such agreements had to be presented to and approved by the Parliament within six months, did not leave much room for the Grand National Assembly to question foreign and defense policies.

Given the aforementioned factors, this study will try to assess why Turkey had been enthusiastic about deploying Jupiters against all odds; the nature of Turkish-American relations in the process; the decision-making mechanism within Turkey's ultra conservative democracy of the time; and the diplomatic, domestic implications of strategic nuclear weapons deployment, culminating in their removal during the Pot Pie operation of 1963 in the aftermath of the Cuban missile crisis of October 1962.

There are at least two arguments as to why Turkey ought not to have agreed to deploy nuclear missiles. First, weapons of mass destruction are not necessarily geared to defend a particular territory, and Turkey was not an exception. Second, countries which share a common border such as Turkey and the Soviet Union cannot afford sustained tensions. Therefore, both countries had to limit and contain risk factors to a minimum. Although Turkey was on NATO's periphery and as such far from the main cluster of NATO countries, it chose to increase its risk factor. There were however some rationales. For example the possession of nuclear weapons was perceived as an excellent deterrent to others. In addition, Alliance strategy assumed that an attack on one NATO member was an attack on all. At a time when Turkey felt vulnerable with increased Soviet influence in the Middle East, and radio propaganda from East Germany broadcast by (Bizim RadyoOur Radio) addressed to potential subversive elements in the country, coupled with Khrushchev's bombastic language against Turkey because of its NATO membership, Turkey chose to opt for what its leadership considered to be the best deterrent: the IRBMs. When Khrushchev coined the phrase 'peaceful-coexistence,' he concomitantly declared that the Soviet Union would support any socialist movements that would result in 'national liberation'. Hence, in Turkey the Soviet threat was perceived to be real, ${ }^{9}$ in an atmosphere when the administration was on alert against any person who might be suspected of leftist tendencies.

A third argument against the deployment of nuclear missiles was that they had deterrence value only as part of strategy of massive retaliation. This strategy became obsolete as the Soviets began to develop IRBMs and ICBMs, and the US policy-makers were becoming ambivalent about massive retaliation. Although the concept of flexible response was adopted as policy during the Kennedy era, it is evident that the seeds were sown during the Eisenhower administration. Turkey employed no analysts, however, who could diagnose such trends. 
Fourth, although there was a nuclear planning group within NATO, the final authority to use nuclear weapons rested with the US President. In case of use, coordination between the White House, the host country chiefexecutive (if at all), respective military personnel (whom in Turkey's case would not be operating on a double-key basis) could have resulted in loss of vital time.

Therefore, retaliation strategies left two options to policy-makers. One was to pursue nuclear warfare, and the second was to negotiate and withdraw. Given the horrors of a nuclear war, the second option had to be preferable. Hence, a third party outside the superpowers which was involved with nuclear systems, would be the subject of negotiation. In essence, this is exactly what happened during the Cuban Missile Crisis to Turkey and Cuba, much to the chagrin of both.

Last, between the time when the US administration offered nuclear missiles to NATO countries in 1957, and in 1959, when Turkey signed a bilateral agreement with the US to accept Jupiters, there existed no compelling reason for Turkey to acquire the missiles. On the contrary, certain developments, both in the Middle East and Europe (such as increasingly strained relations between the Soviet Union and the Western Alliance over Berlin) might have deterred Turkey from taking such a bold stance, but did not.

Developments in the Middle East involved perceptions of Soviet threat, intervention, and infiltration to the regional countries. During the $1956 \mathrm{Suez}$ crisis, Soviet leader Nikita Khrushchev had publicly threatened Britain and France with a nuclear attack if the latter did not withdraw from Suez. The 1958 revolution in Iraq had brought a Baathist regime to power in that country, where increased Soviet influence was a risk factor. Again, in 1958, the sectarian strife in Lebanon seemingly threatened a revolution. Taking advantage of the Eisenhower doctrine of 1957, whereby the US pledged assistance against communist aggression in the Middle East, the Lebanese president Camile Shamun invited US forces into his country. The American unit from Europe used the Incirlik base as a staging point for this operation in mid-July 1958. However,

This action was to place a strain upon the sturdy US-Turkey (sic) relationship. Due to the need for haste in preparation of the force deployment, the Turkish authorities were not able to be consulted on the action; they were notified after the fact of what had occurred. This was viewed in some sectors as a violation of Turkish sovereignty ..."

Further, while European and American journalists had access to İncirlik, the Turkish press corps were denied entry. One month later, however, the Turkish Minister of Foreign Affairs, Fatin Rüştü Zorlu (Foreign Minister 
from 25 November 1957 until 27 May 1960), praised US action in the Turkish Parliament. He defended Turkey's position in facilitating US troop transfers to a small nation facing communist threat. Upon being challenged by the opposition about prior notification, Zorlu made the statement that the US ambassador had asked Turkey's cooperation to use the İncirlik base on 14 July 1958, which the government had granted." Indeed, American soldiers had landed in Lebanon on 15 July 1958, but it would be safe to assume that they were already in Incirlik on the 14th when the US ambassador contacted the Turkish Foreign Minister. Although the American data contradict Zorlu's statements about timing, the Foreign Minister did not seem to perceive a fait accompli in the matter.

The Democratic Party was zealous about fighting international communism at any cost, and Zorlu's foreign policy practice was assertive. He had been recruited to the party (as an MP from Çanakkale) and made a member of the cabinet (first as Minister of State and then as Foreign Minister) from the diplomatic corps. Zorlu was related to the Prime Minister, Adnan Menderes' family through marriage. He was aloof by nature and did not mix with the other party members, nor even with other cabinet members. He felt himself to be above intra party politics and domestic concerns. His mission was primarily to integrate Turkey with the West, and strengthen his country's position through economic and military aid so that Turkey would emerge as the leading regional power. ${ }^{12}$ The method he adopted was for Turkey to act as a 'bulwark' against communism and as a 'staunch' NATO ally. The Prime Minister as Chief Executive, and his Foreign Minister agreed in principle and method alike. And, if proof of dedication to NATO, albeit coupled with other concerns, meant accepting IRBMs in Turkey, then it was to be done.

There did not appear to be consensus among the military about the issue, however. The Turkish Chief of the General Staff (CGS), General Rüşdü Erdelhun had the reputation of being pro-Democratic Party, and worked in harmony with the cabinet. If there were any objections to the deployment of Jupiters from the ranks, officers kept it to themselves. One evidence leading to this conclusion is that Admiral (Ret.) Sezai Orkunt, for example, was with the Turkish Defense Attaché's Office in Washington DC at the time. In a personal interview, he said that he and other colleagues had sent numerous reports to the CGS about the strategic and political liabilities of the missiles. Yet when in the 1960s, Admiral Orkunt became the Director of Intelligence in the CGS, he was curious about the whereabouts of those reports, but could not find a single one in the archives or other dossiers. ${ }^{13}$ In all likelihood, negative reports were destroyed. Whatever opposition there was to missile deployment on the part of the military was to be expressed symbolically. The Jupiter project was given the codename 'İbrahim II' in 
black humor, because there had been only one İbrahim among the Ottoman Sultans and he had the reputation of a lunatic.

On the one hand, it appears that Turkish governments went along with the idea of nuclear missile deployment, because Turkey had grown dependent on the US military and economic aid. This was also another way of showing its gratitude to and solidarity with the US On the other hand, the above mentioned factors such as deterrence and the threat of communist subversion were also foremost in the decision-makers' minds when they made the choice. Counter-arguments appear to be deliberately witheld from the two foreign policy-makers of the time, Adnan Menderes and Fatin Rüştü Zorlu. In the ultra-conservative democracy of Turkey of the 1950s, political will on foreign policy matters was neither shared nor challenged.

\section{Preamble to Deployment}

At the NATO Heads of Government meeting in December 1957, IRBMs were introduced to Italy and Turkey, because, as the communiqué read,

The Soviet leaders, while preventing a general disarmament agreement, have made it clear that the most modern and destructive weapons, including missiles of all kinds, are being introduced in the Soviet armed forces. In the Soviet view, all European nations except the USSR should, without waiting for general disarmament, renounce nuclear weapons and missiles and rely on arms of the pre-atomic age. ${ }^{14}$

Therefore, NATO had to stockpile nuclear warheads to be made available to the Alliance as and when needed. The US was prompted to take action, because the Soviets had developed a long-range missile initiated by the Sputnik experiment in October 1957. The myth of a 'missile gap' between the US and the Soviets soon became prevalent in the American media. Although the US policy-makers knew better, the myth had to be propagated perhaps in order to justify military/defense spending coupled with the more altruistic policy of controlling nuclear proliferation in Europe within the bounds of NATO, as well as strengthening the Atlantic linkage.

Subsequently, General Lauris N. Norstad, the Supreme Allied Commander Europe (SACEUR), was the authority to have decided on Turkey and Italy for NATO IRBMs. A US State Department memorandum concurred that while the decision was not based 'upon any known targeting by the Soviets of specific sites in the two countries, it must however have been assumed that key targets in those countries would be subjected to the Soviet missile threat.' ${ }^{15}$ Although in the same report it was indicated that the 'decision of the Italian and Turkish governments were those of free partners 
entering willingly into a project in the mutual Alliance interest and in fulfillment of agreed Alliance objectives serving the maintenance of peace', previous data from 1956 indicate that the Americans had to do some lobbying in Turkey to build up an atmosphere conducive to deploying sophisticated and massive weaponry, even if nuclear missile deployment may not have been the issue at that time.

In a 'Top Secret' memorandum from the US Embassy in Ankara to the US Secretary of State on 17 April 1956, it was stated that plans for massive deployment of US air and ground forces and 'special weapons' in Turkey would be a difficult proposition for the Turks to accept if put unilaterally. One reason being that they were keen on being consulted about US policies regarding the Arab-Israeli conflict in particular, and on policies regarding the Middle East in general 'with relatively little to show for their pains'. Not having been taken in as full partners, in addition to 'Moscow's warning against interference sometime ago, Turkish cooperation in a military venture of this magnitude involves some major risks for them, from the other side of their northern borders.' ${ }^{16}$ The memorandum asked for authorization to share information with the Turks so as to gain receptivity for massive US military force and 'special weapons' deployment. It is not clear, however, whether such authorization was given. In any event, American lobbying with the Turks to accept 'special weapons' in the context of modernizing the Turkish military probably sufficed. Modernizing its military with nuclear missiles, however, was to become Turkey's Achilles heel.

General Norstad's decision on nuclear deployment in NATO countries was made in light of President Eisenhower's concern about conducting the US military aid program overseas by extending protection under the nuclear umbrella and reducing the number of conventional forces. ${ }^{17}$ By September 1958, the US State Department approved that the Military Facilities Agreement of 23 June 1954 with Turkey be amended to include USAF's development and expansion of the Çiğli Airfield near İzmir, because SACEUR had designated the USAF as the primary user of that base. The objective was to bring the base up to USAF standards for maneuver and rotational training operations. ${ }^{18}$ Çiğli's infrastructure was being developed to eventually accommodate more sophisticated weaponry such as IRBMs.

In April 1959, the US Department of State was ready to conclude bilateral agreements under the Atomic Energy Act in implementation of the NATO Atomic Stockpile concept between the US and Turkey. ${ }^{19}$ While Greece remained ambivalent on the southeast flank, discussions with Turkey continued. The Turkish Ministry of Defense agreed with SACEUR's letter parting from the Italian case 'only with respect to command agreements that it did not propose the creation of an Intermediate Turkish 
Missile Command, but reserved this as a possibility to be considered if more than one IRBM squadron were deployed in Turkey.' ${ }^{20}$ In the Pentagon's estimation, Turkish acceptance of this letter had opened the way for bilateral negotiations.

Yet, throughout 1959, completion of infrastructure projects were stalled, because Turkey failed to meet its financial commitments for cost sharing. NATO had expended over US $\$ 200$ million on infrastructure for airfields and facilities, but it still did not have an operational system or a fully operational or completed airfield. Turkey had been unable to appropriate funds in its defense budget to meet expenses. Reportedly, Turkey's 1959 Ministry of Defense budget for infrastructure required TL 104.9 million (US $\$ 12$ million), but it had appropriated only TL 23 million (US $\$ 2,5$ million) out of counterpart funds. In view of Turkey's financial and budgetary difficulties, US officials recommended to the Secretary of State that Washington should maintain reservations until it received a satisfactory memorandum from Turkey on program deficiencies. It also advised that it should also re-examine its aid program 'to determine what financial measures (such as release of additional counterpart funds earmarked for use in completing host country responsibilities on high priority projects) can be employed to insure operational completion of projects now under way. ${ }^{21}$

As of 1956, the tide had begun to turn for the Democratic Party administration. Concurrent with major development projects was mismanagement of resources; bad weather and harvests eradicated benefits to be derived from massive purchases of tractors for agriculture; trade and budget deficits had increased; the opposition began to be sharply critical; and the government became more authoritarian and oppressive.

Meanwhile, the IRBM issue remained alive with the US State Department and USAF, who were trying to determine how much of the costs would be met by the MAP (Military Assistance Program) and how much by the Air Force. With respect to the location of IRBMs, the State Department favored a remote spot while the AF preferred one near İzmir which would locate the missiles close to a major port. The Çiğli airfield, then, remained the only choice. ${ }^{22}$

In due course, President Eisenhower had begun to question the presence of bases in NATO flank areas. The President viewed such bases as imposing a political drain and a 'constant burden and handicap on our foreign affairs'. But the Undersecretary of State, Douglas Dillon, reminded the President that 'it would be a very serious matter to back down on our plans at the moment, apparently under threat from Khrushchev. Also, if we were to treat Greece and Turkey differently in NATO from other countries, we would encounter great difficulty, especially with Turkey. ${ }^{23}$ Dillon was of the opinion that IRBMs placed close to Soviet border might compel them to 
consider disarmament seriously. Despite these arguments, Eisenhower pondered whether the US and the Western Alliance were not behaving in an unduly provocative fashion by deploying IRBMs close to the Soviet Union.

The US military-civilian bureaucracy, keen on upholding their credibility and commitments, followed the course of deployment. By September 1959, the US Embassy in Ankara was authorized to begin negotiations with the Turkish government for an agreement to deploy IRBMs in Turkey. Prior to receiving a proposal to that effect, the Turks had indicated to SACEUR their willingness to accept the offer. Zorlu was reportedly very anxious to sign the proposed agreement without change before departing for the UN General Assembly meeting in New York on 19 September 1959.

The crux of Zorlu's insistence on concluding the agreement may have rested on the fact that Khruschev was to be present in New York. ${ }^{2+}$ The State Department, however, recommended that a public announcement about exchange of notes between Turkey and the US to deploy IRBMs on Turkish territory be made, but only as a low key announcement after the North Atlantic Council notification. 'Should any authority be asked whether there was any significance to the fact that this agreement was concluded and announced at the time of Khrushchev's visit to the US the reply would be that there was no significance about the timing of this announcement.. ${ }^{25}$ The agreement, moreover, would not be made public, because notes exchanged between the two governments included operational details and they would therefore not be made public.

In fact, Zorlu wished to impress upon Khrushchev that Turkey could not be bullied. But, he failed to make the impression on Khruschev, because,

Within a week the avid Turkish government accepted the US draft agreement without alterations and proposed that the Americans conclude the deal immediately. Secretary of State Herter and Norstad endorsed this rash Turkish approach, but it was Eisenhower himself who deferred the signing of the understanding until the end of October 1959 - well after Nikita Khruschev's September visit to the United States. ${ }^{26}$

If the haste and eagerness on Zorlu's part to sign the agreement seem overzealous, John Haskell from the Office of Defense Advisor (US Mission to the NATO and European Regional Organizations), was supportive of transferring nuclear delivery capability to the allies, despite the risks. In a memorandum to the Acting Chief of Mission, USRO, Haskell stated 'However great may be the risks in helping NATO countries to achieve, either under SACEUR control or independently, nuclear delivery capability, I believe that such risks are inevitable and much less than the threat to the 
world that failing to assist them - and, in fact, retarding their efforts to meet the more technically advanced nature of the Soviet military threat.. ${ }^{27}$

Consequently, major policy-makers from the US and the ruling elite in Turkey, viewed the deployment of nuclear missiles as a risk worth taking. Meanwhile, already in May 1959, the Soviet Union had delivered a verbal note to Turkey asking the latter to account for press information regarding deployment of nuclear missiles in Turkey. The note included a veiled threat that the Soviet Union would take measures to defend its southern borders and an accusation that Turkey was becoming party to NATO's offensive aims by allowing 'rocket bases' to be built on its territory. ${ }^{28}$ Turkey justified its decision on the basis of its membership in a collective defense pact. On 25 June 1959, the Soviet Union made a declaration on the establishment of an atom free zone in the Balkans. It is quite probable that this note played a role in Greek ambivalence, albeit coupled with other concerns such as domestic opposition. The Soviets argued that 'As a result of pressure on the part of the USA. the Governments of Turkey and Italy have decided to establish on their territories American atomic and rocket bases, and thus to use the strategic position of the Balkan peninsula for aggressive purposes. ${ }^{29}$ They further called for Turkey and Italy to review their positions on this question. Both countries however remained intransigent.

By 15 October 1959, a leading Turkish daily made the announcement that an agreement had been concluded between the US and Turkey on building rocket sites ${ }^{30}$ although the US had not yet ratified the agreement. The announcement appears to have been made under orders from the government in order to accelerate US ratification. It was only by the end of October 1959, that the Turkish press reported an announcement of the US Department of State that Turkey had agreed to the establishment of an IRBM base, the missiles of which had the capacity to deliver nuclear warheads, classified as Jupiter IRBMs. ${ }^{31}$

\section{The Kennedy Factor}

It was one of history's coincidental twists that while President Eisenhower almost had a premonition in drawing parallelisms between deploying nuclear missiles so close to the Soviets in Turkey, and a theoretical deployment of Soviet missiles in Mexico, it was during the Kennedy administration that these weapons were installed in Turkey late 1961, to fulfill the 1959 agreement. There seems nothing peculiar about fulfilling an agreement. What is peculiar, however, is that even a report such as the following from the Joint Committee on Atomic Energy of 11 February 1961 did not stop the deployment of Jupiters in Turkey. 
Compared with the solid-fuelled mobile POLARIS missile or second generation medium range ballistic missiles offered by former Secretary Herter in his speech before the NATO Council in December of 1960, the liquid-fuelled fixed JUPITERS are obsolete weapons. Since they will not be placed in hardened bases and will not be mobile, their retaliatory value is highly questionable. In the event of hostilities, assuming NATO will not strike the first blow, the USSR with its ballistic missile capability logically could be expected to take out these bases on the first attack, which undoubtedly would be a surprise attack ... Construction, therefore, should not be permitted to begin on the five JUPITER sites in Turkey. ${ }^{32}$

But, between April and September 1961, six surface shipments were made to İzmir of Jupiter missiles and support systems followed by seven shipments by air between June 1961 and January 1962. ${ }^{33}$

Why did President Kennedy agree to go ahead with the deployments despite advice to the contrary, while he was trying to negotiate for arms' limitations with the Soviets? According to a seemingly definitive interpretation, Kennedy did not wish to look weak after his encounter with Khruschev in Vienna. The 3-4 June 1961 meeting in Vienna had left

JFK convinced that Khrushchev would not shrink from pulling the nuclear trigger if his back was to the wall. The entire US strategy in the Cuban missile crisis a year later was based on this analysis, which proved to be correct. Because Khruschev was given leeway to maneuver, he did not reply in kind to our show of force against Soviet ships and his Communist ally, Castro. ${ }^{34}$

Further yet, the 'leeway to maneuver' after agreeing to US inspection of Russian ships during the 1962 quarantine of Cuba, and the subsequent promise that the US would not invade Cuba might have had something to do with the seeming compromise that, in Khruschev's own words was explained as,

President Kennedy told us through his brother that in exchange [of removing Soviet Missiles from Cuba] he would remove missiles from Turkey. He said: If this leaks into the press, I will deny it. I give my word I will do this, but this promise should not be made public. ${ }^{35}$

In essence, President Kennedy was hardly making a concession. 'The Jupiters were no longer useful strategic balance-wise. In 1958-59, they could have been useful, but only when accompanied with ICBMs and Minutemen., ${ }^{36}$ The US was moving ahead very rapidly with technology. The broad technical strategic argument alone rendered the Jupiters obsolete. 
Although lip service was paid by the 1960 coup-makers that 'the Democrats had sold the country to the US', no one questioned the presence of strategic nuclear missiles on Turkish soil. Far from it, there was resistance to all American approaches for their removal until the Cuban missile crisis occurred, and Turkish policy-makers came to the realization of how close the country might have come to becoming a Soviet target. Before the Cuban crisis, the belief in government circles was that Turkey was a target without the Jupiters, anyway. But the distinction of being just a target and a nuclear target seems to have settled in among the Turkish politicians after the Cuban Missile Crisis.

During the Cold War, it was difficult at best, if not impossible, to differentiate between fact and fiction. Moreover, the ban on teaching Marxism/Leninism, Communist Systems, Russian History and Thought deprived the first two generations of the Turkish Republic of any sense of a realistic assessment of this neighbor. Aggressive Soviet behavior did not help much either. But, subjects such as the Soviet Union, Russia, Communism, Turkic People's of the Soviet Union became the monopoly of radicals, not well-versed 'communists' and not well-versed 'Pan-Turkists' alike. These groups remained marginal in the 1940s and 1950s, only to reclaim their conceptual territory, even though they lacked factual information, to the detriment of the country. The polarization of the 'right' and the 'left' in the 1970s and their resort to terrorism resulted in the third coup d'état in Turkey by 1980 . The previous ruling parties, both Republican and Democratic (and their successor the Justice Party), have been responsible for ideological polarization by equating dissension and liberalism with treason. Under those circumstances, a sacrosant issue such as foreign relations entrusted to any incumbent government was naturally considered above scrutiny, in the hope of keeping foreign relations above domestic party politics. This literally meant integrating Turkish foreign policy with NATO, alias the US, for the US was equal to NATO on Turkish territory until the crisis over the Jupiter missiles, the Cyprus issue, limitation of opium cultivation, problems with SOFA (Status of Forces Agreement) and sovereignty issues, and other issues brought Turkey to make a conceptual distinction between its commitments to the US bilaterally and to NATO multilaterally, in accordance with its basic foreign policy tenets.

\section{The Road to Deployment}

Caught between the desire to attain NATO force goals, modernizing its military and strengthening the economy, Turkey by 1958, had grown increasingly dependent on US aid. The government was not about to spend any time worrying about political correctness when the situation involved 
'friendship with the US'. This was reflected by Zorlu's behavior in the use of Incirlik-for-Lebanon case. Prior to Zorlu's ministry, however, there was real concern about the image of equal partnership. For example, in May 1957, the Turkish Assistant Secretary General for NATO Affairs in the Ministry of Foreign Affairs, Hüveyda Mayatepek, had called the US Ambassador to Ankara, Fletcher Warren, and expressed concern over the possibility that USAF rotational units might arrive in Adana 'without foreknowledge of the Turkish Government and that present (sic) release by SACEUR might be issued without prior consultation with Turkish government. ${ }^{37}$ A press release at the time of discussion of deployment at the Atlantic Council was enough to satisfy the Turks. Although this would not change the substance of plans either way, an appearance of correctness in relations prevailed.

By 1958, Turkey was in deep economic crisis and US economic aid was limited to the amount believed necessary by the Americans to prevent a collapse. Turkey's annual deficit in the balance of payments was approximately US $\$ 350$ million (Turkey agreed to an economic stabilization program only in 1959) ${ }^{38}$ Hence, the excitement expressed in the press about US aid. On 14 January 1958, an editorial in the daily Vatan said that Turkey should carry out radical internal reforms to make it possible for the US to assist the country economically and warned that US interest in Turkish welfare may disappear should Washington reach a rapprochement with the Soviets. The following day Cumhuriyet called for a sharp increase in aid programs. In the same article, Turkey was credited with being the only possible NATO site for IRBMs directed against Russia and stated that Turkey refused to profit from its strategic position by not bargaining with Russia. The latter statement was obviously made for American consumption, but one probably dictated by a government caught between its commitment to sovereignty and excessive dependence. Requests for increased military aid were justified on the basis of increased Turkish share in the collective defense burden..$^{39}$ The foreign aid that Turkey received in 1958 amounted to US $\$ 359$ million of which $\$ 234$ million was granted by the United States. The rest came from OEEC, IMF, the Federal Republic of Germany and Britain. ${ }^{40}$ Yet, given the budget and trade deficits, domestic credits were frozen, price increases as well as shortage of goods occurred with ensuing inflation, black market and queues. Zorlu tried to account for the economic problems by stating that Turkey had incurred medium term loans for investments and repayment dates for these loans came before the government managed to make investments operational and profitable.

But, one thing was clear: the government was getting desperate both domestically and in the conduct of foreign affairs. It is, therefore, plausible that economic considerations and dependence particularly on US aid 
contributed to the decision to accept missile deployment in Turkey. In this way, the US would also become dependent on Turkey through its custody of nuclear warheads on Turkish soil. In addition, after the US spent US $\$ 100$ million on each Jupiter squadron and developed support systems, Turkey, in all likelihood would be guaranteed continued American economic and military assistance.

In addition, NATO had expended US $\$ 200$ million on all infrastructure works in Turkey (approximately. US $\$ 90$ million on airfields and US $\$ 60$ million on POL-Petroleum, Oil and Lubricants- facilities), but by the close of May 1959, there was still not an operational POL system or a fully operational airfield. However, Turks would not welcome any suggestion to reallocate national funds to meet host country responsibilities. ${ }^{41}$ Minister Zorlu had already requested from Secretary Dillon the release of TL 810 million (US $\$ 90$ million) worth of counterpart funds for military purposes, but the State Department believed that the release of additional counterpart funds would go to finance Turkish state enterprises. The matter was left to negotiation along with Turkey's defense budget of FY $1960 .^{42}$

In spite of its economic problems and limited military capabilities, Turkey was perceived as an aggressive nation in some circles of the State Department. On 4 February 1959, Secretary John Foster Dulles, told General Norstad that some people in the Department were opposed to IRBMs for Greece and Turkey. Opposition regarding Turkey might have stemmed from the aggressive stance that the Menderes government displayed in the aftermath of the coup d'état in Iraq in 1958. Specifically, Menderes wanted Turkey to take military action and eliminate the leftist coup-makers in Iraq, only to be convinced by the Americans to refrain from such an act.

General Norstad had already announced that Turkey was going to get IRBMs the previous December, in addition to Secretary of Defense, Neil McElroy, who announced on 23 January 1959, that negotiations were underway with France, Greece and Turkey for IRBM deployment. But, Norstad said,

if people were worried about the Turks misusing IRBMs, we could drag out indefinitely arrangements under which we would have to keep US personnel present and eliminate thereby such theoretical risk. The Turks were obviously not ready to move into any situation of full control over the IRBMs immediately. ${ }^{43}$

By the beginning of April 1959, Turkish newspapers announced Zorlu's meeting with Secretary Christian Herter and Loy Henderson of the State Department about bases to be established in Turkey which would host 'guided weapons' or 'rockets'. ${ }^{4}$ Devoid of any information as to what these 
terms meant, and in the absence of any reference to nuclear delivery capabilities of these 'rockets', a public debate over the issue did not surface.

The Soviet Union, however, delivered a note to Turkey threatening that if the decision was implemented, it would take the necessary precautions to defend its southern border. ${ }^{45}$ On 13 July 1959, the Turkish Foreign Ministry responded to the June proposal of the Soviet Union regarding an atom free zone in the Balkans by stating that Turkey was not forced by the US to accept atomic 'weapons'; that since it was under threat it had the right to legitimate self-defense through most advanced weaponry; and that this proposal of the Soviet Union which intended to deprive Turkey of sophisticated weaponry, but leave intact its own, was proof that Turkey had made the right decision. ${ }^{46}$ Hence, the official announcement of IRBM deployment in Turkey was to read,

In accordance with the decision of the NATO Heads of Government meeting in December 1957 and the recommendation of SACEUR, an exchange of notes took place in Ankara on between the United States and Turkey providing for the deployment of IRBMs in Turkey. In addition to provision of the missiles themselves, the United States will extend training assistance to enable the Turkish armed forces to man and maintain the missile under the operational control of SACEUR.47

In addition, the US embassy in Ankara was instructed in anticipation of questions that (a) information on the number of missiles was classified, (b) no information could be given about the type of missiles to be deployed, (c) no specific date for deployment was set, (d) location of bases in Turkey had not yet been determined, and regarding a possible query whether nuclear warheads will be turned over to the Turkish government, 'We will not, repeat, not confirm or deny presence of nuclear warheads in any country. However, US law requires US-manufactured nuclear warheads must remain in US custody. ${ }^{48}$ Meanwhile, not a single public Turkish document was referring to nuclear warheads at the time.

The 'Agreement of Cooperation Between the Government of the United States of America and the Government of the Republic of Turkey' signed on 5 March 1959, was presented to the Committee on Foreign Affairs at the Turkish Grand National Assembly (GNA) only by 6 February 1960 , although international agreements were to be presented to the GNA within six months of their signing for mandatory ratification. The clause which stated that the US and Turkey 'affirmed their determination to maintain their collective security and to resist aggression direct or indirect' (emphasis added) caused consternation among the opposition. A Republican MP from Ankara, Bülent Ecevit, seriously questioned this clause, which opened the 
way for US military intervention in case of an 'indirect' threat to the incumbent regime, whatever the word indirect meant.

Ecevit was concerned about the state of democracy in Turkey. He reminded the Assembly that when the Lebanese President Chamun sensed that he was losing to the opposition, he declared the matter as an infiltration attempt by international communism, and invited the US military to intervene. ${ }^{49}$ It is not within the scope of this study to assess whether Chamun was being an opportunistic politician or whether the communist threat was real in Lebanon. But, given the growing authoritarianism of the Menderes government, Ecevit's questioning of the Agreement was valid. However, the government had no time to spare on details, namely, democraticallyinclined bickerings of opposition parliamentarians. The agreement was ratified.

Throughout 1960, there were tangible developments in Soviet-Turkish relations which were hardly a reflection of easing of East-West tensions. In October 1959, Menderes complained at the Dallas Council on World Affairs meeting that the inflated defense budget of Turkey in view of the Soviet threat was causing financial problems in development projects. ${ }^{50}$ Paradoxically, Turkey had no intention of reducing its defense budget. Its intended rapprochement with the Soviets was based on its frustration with the US aid levels for development projects. The Menderes government plausibly wanted to play the trump card of rapprochement against the Americans for increased levels of aid.

By April 1960, declarations were made that the Soviet and Turkish premiers would be visiting each others' country. The visits did not take place, because on 27 May 1960, there was a military coup in Turkey. The first announcement of the coup-makers emphasized that Turkey would remain in NATO and CENTO. Colonel Alparslan Türkeş of the National Unity Committee, who served as an Under Secretary of the Prime Minister's Office- disclosed recently in his memoirs that the Soviet Ambassador, Nikolai Rijov delivered a message from Khruschev soon after the coup. The Soviet Premier offered Turkey US $\$ 500$ million annually in foreign aid in return for Turkey's abrogating its NATO membership. Moreover, the Soviets were ready to modernize the Turkish Armed Forces. Rijov expressed Soviet concern over US bases in Turkey as well as tactical nuclear weapons and missiles capable of nuclear delivery. ${ }^{51}$ The latter had not yet been delivered, but the issue must have disturbed the Soviets to the point where they came up with very advantageous offers to the new ruling elite, which did not concur.

In 1960, HQ USAFE programmed one SM-78 Strategic Missile Squadron for Çiğli Air Base, with five launch positions to be completely operational by February 1962 . While the US would have custody of the 
nuclear warheads, Turkish Air Force personnel were schooled in the operation of the IRBMs in preparation for turning them over to the host country.

In mid-August 1961, after completing the Italian sites, 275 Chrysler technicians moved to Turkey, where they began to install the 15missile NATO II squadron. The first launch positions became operational on November 6,1961 . A second position came on alert the following month, and the fifth and final position became operational on March 5, 1962.52

In 1961, President Kennedy asked the former Secretary of State Dean Acheson, to conduct a study assessing NATO policies. There were suggestions in the study group that Acheson formed, to the effect that IRBMs in Italy and Turkey should be removed. When the President asked George McGhee of the study group whether the Turks would be amenable to such a proposal, McGhee said he did not think so; however, they would explore the possibilities. ${ }^{53}$ Actually, it was the critical report from the Joint Atomic Energy Committee of the Congress (fn.28) which had stirred the President to search for ways to remove the Jupiters. Referring to their obsolescense and vulnerability, the Secretary of State Dean Rusk reminisced, 'I remember that we joked about which way the missiles would fly if they were fired.' President Kennedy asked Rusk to take up the matter with the Turkish government which he did during a CENTO meeting in Ankara on 1 May 1961. According to Rusk,

after dinner, I had a walk in the garden with Mr. Selim Sarper, the Foreign Minister of Turkey, and took up with him the matter of withdrawing the Jupiters from Turkey. He expressed considerable concern on two grounds. First, he said that the Turkish government had just gotten approval in its Parliament for the Turkish costs of the Jupiter missiles and that it would be very embarrassing for them to go right back and tell the Parliament that the Jupiters were being withdrawn. ${ }^{54}$

Moreover, such an action would be demoralizing before the Polaris submarines became available in the Mediterranean, and that was not scheduled before Spring 1963. When Rusk briefed the President on these points, Kennedy agreed to delay any action. Kennedy's concern about looking 'weak' in Soviet eyes was clearly enhanced by the Turkish attitude. Moreover, after the following definitive memorandum from McGhee, the matter was dropped: 
(a) It has been concluded that action should not be taken to cancel projected deployment of IRBMs to Turkey.

(b) This conclusion is based primarily on the view that, in the aftermath of Khruschev's hard posture at Vienna, cancellation of the IRBM deployment might seem sign of weakness. Moreover:

(i) When the Secretary of State raised this matter with the Turkish Foreign Minister at CENTO, the Turkish reaction was strongly adverse. (ii) When the Turkish Foreign Minister discussed the problem with SACEUR, General Norstad underlined the military importance of sending IRBMs to Turkey. This made it unlikely that any attempt to persuade the Turkish military that they should abandon this project would succeed.

(c) The Secretary of State has discussed this conclusion with General Norstad, who concurs. ${ }^{55}$

By July 1961, W-49 warheads for Jupiter missiles in Turkey were released. A report from HQ Tuslog (Ankara, USAFE) covering the period 1 July - 1 December 1962 stated that, (a)The Directorate of Ballistic Missiles was established in HQ Tuslog on 15 August 1962; (b) The operational status of the Jupiter missiles during this period of time was well above the required 70 per cent 'in commission' SHAPE standard (Actual incommission rate during period, 91 per cent) and the first launch position was turned over to the Turkish Air Force on 19 October 1962; (c) Construction of İbrahim II (codename for the Jupiter project) facilities was considered 100 per cent complete in December 1962; (d) interim agreement for US use of Çiğli Air Base was signed by Commander, TUSLOG and Commander, Turkish Air Force on 11 December 1962; and (e) training of both USAF and TAF personnel in the Jupiter Weapon system is on schedule and failures have been negligible. ${ }^{36}$ Meanwhile, events that unfolded in a remote island on the Atlantic were to engulf the 'Turkish Jupiters'.

\section{The Cuban Missile Crisis and the Jupiters: Domestic and Foreign Policy Implications for Turkey}

The Cuban Missile Crisis has been studied extensively especially in light of new documents becoming available to scholars. In essence, a parallelism would be drawn between the Soviet missiles in Cuba, and the Jupiters in Turkey was a foregone conclusion, even though the Turkish press argued to the contrary, stating that Turkey was part of a collective security system while Cuba was not. ${ }^{57}$ When the crisis unfolded, the Soviet Minister of Foreign Affairs, Andrei Gromyko, met President Kennedy and Secretary Rusk in Washington DC on 18 October 1962. Gromyko tried to justify the 
Soviet position:

You obviously will not deny the presence of American military bases and numerous military advisors in Turkey and Japan, let alone Britain, Italy and other West European countries ...Thus, the USA may have bases in those countries and conclude military treaties with them, yet you do not believe the USSR has the right to help Cuba to develop its economy and strengthen its defensive capability. ${ }^{58}$

Dean Rusk replied that the Soviet Union was 'exaggerating the role of US bases abroad'. But was it?

In fact, it was not only the Soviets who drew a parallel between the two situations. On 29 October 1962, the Turkish representative on NAC stated that 'his government asked him to emphasize how unfortunate it was that press in several NATO countries had urged a deal of Jupiters for Cuban missiles which obviously encouraged Khruschev to make a public offer. ${ }^{59}$ Furthermore, the British liberal daily The Guardian had even stated that the Soviets may be justified in imposing a blockade to Turkey in retaliation to the US blockade of Cuba. A Turkish journalist reacted to this by saying how grateful he was that the conservatives were in power in Britain and not liberals, "who live on the Moon. ${ }^{60}$

İsmet İnönü, once again Prime Minister in 1962, handled the repercussions of the crisis in as low a profile as possible. The domestic implications of the crisis, however, later, were nowhere nearly as smooth. In contrast with Italy, where the removal of the Jupiter missiles facilitated a consensus between the Christian Democrats and Socialists, ${ }^{61}$ in Turkey it served to widen the gap between the Right and the Left. The issue was not the removal of the IRBMs per se. The leftists argued that the Americans had been bargaining with the Soviets behind Turkey's back, and that a tradeoff between the Soviet missiles in Cuba and the Jupiters in Turkey pointed only to what an unreliable ally the US was. Consequently, Turkey's membership in NATO only endangered its security, because if there was ever a nuclear attack on Turkey, the NATO allies would not retaliate in kind, but would probably turn the issue into a bargaining chip with the Soviets.

During the height of the Missile Crisis on 27 October 1962, Kennedy suggested talking to the Turks at a National Security Council meeting and 'point out to them the great peril facing them during the next week'. But the President immediately abandoned the idea on further thought because 'the Turks' he said 'were now in no position to make a statement to the effect that they would ask that the Jupiters be withdrawn' ${ }^{62}$ Kennedy was right. Just as these problems were being debated in the White House, the Turkish government had issued a press statement rejecting outright Khruschev's public offer of a tradeoff between the Jupiters and S-4s. Even then, Kennedy 
reiterated: 'We cannot propose to withdraw the missiles from Turkey, but the Turks could offer to do so. The Turks must be informed of the great danger in which they will live during the next week and we have to face up to the possibility of some kind of a trade over missiles. ${ }^{63}$

It appeared that the Turks had put themselves in an intractable position by issuing a public statement rejecting Khruschev's proposal of a trade-off. This is perplexing, given the fact that the Turkish Chief Executive was İsmet İnönü, who had conducted brilliant diplomacy during World War II so that Turkey would not get involved in the war, in spite of its military alliance with Britain and France. Why did İnönü forego the opportunity to play the role of an 'honest broker' in the crisis and did not make such an offer before KhrusHchev did?

The missile crisis was made public on 22 October, and Khruschev made his proposal on 26 October. There were already indications from the Western press drawing a symmetry between Cuba and Turkey. İönü was briefed immediately after the 22nd about the liabilities of the missiles at least in regard to the decision-making process of their use. ${ }^{64}$ Was faith in NATO so strong, or national pride in refusing to be compared with a small island so great, that İnönü did not grasp the initiative, are questions which cannot be answered definitively at this point in time. The answers to these questions may well be yes, but the lack of a message from the US one way or another (except to ask for support in the Cuban quarantine) must have given the Turks a false sense of security. Left to his own devices, Inönü chose to stand firm against the Soviet demand. It had worked in the past when Turkey was not even a member of any alliance. Having stated that, however, one has to note that İnönü's and Turkey's traditional foreign policy was to remain cordial with the Soviets. Turks took an uncompromising stance against the Soviets only when challenged by them. And, this one was not an exception either. Meanwhile, in Washington DC,

Kennedy realized that world opinion would never comprehend why Soviet missiles in Cuba were different from American missiles in Turkey. He knew that he had to make a trade rather than risk war over the obsolete Jupiters, but he apparently decided early on that he would keep this move as his trump card, to be used only at the end rather than the beginning of the negotiations. It seems clear now that he would have given up the Jupiters through some form of UN mediation, but by bluffing so well that he even fooled most of his advisers, he was able to force Khruschev to accept his terms without disclosing the secret concession regarding the missiles in Turkey. ${ }^{65}$

The idea of 'talking to the Turks' occurred to Kennedy only after Khruschev's offer. In the meantime, reports from the US Embassy in 
Ankara which evaluated the Turks as "courageous and proud people who do not understand the word compromise' might have blocked the US initiative in this regard even if they were sent prior to 27 October. I have argued elsewhere that the Turks may be proud and courageous - no more or less than others - but were definitely not suicidal. ${ }^{66}$ The gist of the matter, once again, remained in bilateral incohesion. While one cannot rule out Kennedy's personal ambition to gain a political victory against the Soviets all by himself - without involving a remote third party such as İnönü- it nonetheless had a spillover effect in Turkish-US relations. On 27 October, even Kennedy was in a dilemma, acknowledging that he might need the Turks. By then, both the Turks and the US President had publicly launched an irreversible course, except that Kennedy had already conducted secret diplomacy with the Soviets, but not with an ally.

President Kennedy had not taken Inönü into his confidence and this factor, more than a 'bargain' or a 'trade-off', was significant for the future of the collective alliance as well as for bilateral relations. Had Kennedy been briefed on İnönü's diplomatic skills and his standing in the country on or before 22 October, a dialogue with Turkey might not have come to him as an afterthought when it was already too late for Turkey to retract from its position.

İsmet İnönü's moral authority had failed to stop the executions of the Democratic Party's ministers, Menderes, Zorlu and Polatkan in 1961. And, it may well be questioned whether that very moral authority would have held, had he been convinced to offer in 1962 to remove the Jupiters for the sake of world peace. The chances were that it would have worked despite the apparent military insistence on holding on to the missiles. Good sense alone would dictate that the military would welcome the opportunity to clear the Turkish Armed Forces' name of the stain of having executed elected politicians, by engaging in the grandiose scheme of contributing to world peace. The Turkish Armed Forces already had a keen sense of public relations trying to distinguish itself from the coup makers of Iraq of a couple of years ago, as well as from the National Unity Committee faction which had signed the death warrants. Yet four days, from 22 until 26 October (in essence, from 13 October when the Cuban missiles were identified) might have been enough time to test these hypotheses had misperceptions about Turkish behavior been absent and alliance cohesion been intact.

\section{Conclusion}

Justifying the existence of Jupiters as a NATO issue, thus distinguishing it from the bilateral relations between Turkey and the US, therefore claiming that no symmetry existed between the former and that of bilateral relations between the USSR and Cuba was a face saving device. This did not, 
however, alter the risk factors associated with these dangerous liaisons during the Cold War.

The two decision-makers who decided to deploy nuclear missiles in Turkey, Menderes and Zorlu were not alive by the time of the Cuban crisis. They were sentenced to death following a legally flawed trial and were executed in 1961. In 1962 and 1963 there were two other coup attempts. Therefore, domestic concerns took priority over foreign policy as well as defense until the 1964 Cyprus crisis, and the subsequent tension between the US and Turkey over the Johnson letter. President Johnson, by cautioning Inönü that if Turkish action on the island would invite a Soviet attack, then NATO was not obligated to defend Turkey, brought home the fact that the security interests of Turkey and the Western Alliance were not necessarily the same. Then, if NATO was not obligated to Turkey over Cyprus, why should NATO have been obligated to it over a potential nuclear war yet over another small island?

The 1961 Constitution had brought Turkey freedom of the press, expression, and of association. In this liberal milieu, foreign policy was also being discussed publicly for the first time. The Johnson letter made it obvious that Turkey's national security interests were not always going to be convergent with those of its allies. Concomitant with the Johnson letter, news leaked, presumably from the Soviet Embassy in Ankara, that President Kennedy had agreed to a trade off of the Jupiters without informing the Turks during the Cuban crisis.

Although scholars can only recently verify such a verbal assurance from Kennedy to the Soviets, the Turkish left believed it wholeheartedly at the time. Coupled with the Johnson letter, anti-Americanism and neutralist sentiments grew on the part of liberals and socialists alike. They argued that all bases in Turkey were US bases, with the exception of the İzmir NATO Headquarters, which was a showcase, and that Turkey had lost its sovereignty to the US - an unreliable ally at that. In sum, even though the repercussions of the Cuban Missile Crisis (even if it was mis-diagnosed) and the Johnson letter were not the sole determinants of the polarization between the Leftists and Conservatives in Turkey, they clearly contributed to it.

Disassociating US domination from the entirety of Turkish security interests, came in increments. The Jupiter case, although assessed without any precision, should have been the first step in that direction, but it was lost in 1970s rhetoric. Criticism was directed at the Turkish governments' accommodation of US listening posts, bases, and radar sites on Turkish territory. The Turkish soldiers only patrolled the fences of such installations, which subjected uncontrolled American military presence in Turkey to polemics alone, and not to serious debate. Therefore, pro- and non- 
Americanism became polarized. This trend, once again, probably will not lend itself to concrete evaluations of either the US or the USSR in official Turkish documents (when they become available). The nature of bilateral relations under the umbrella of NATO 'secrets' might remain a mystery for a long time to come, although they may have had only an indirect relationship with NATO.

Only by 3 July 1969, a Defense Cooperation Agreement (DECA) was signed by the US and Turkey 'in order to consolidate the various bilateral accords that had accumulated over the years' ${ }^{67}$ Some of those accords were verbal, some written, but remained top secret. Upon proddings by leftists and liberals alike, followed by several incidents caused by uncontrolled US flights compromising Turkish sovereignty (e.g. the U-2 incident of 1960 , RB-47 reconnaissance aircraft accident in the Black Sea, and the downing of a US military aircraft by the Soviets in 1967), the Turkish government, by 1970 , announced that the Military Facilities Agreement of 1954 with the US was abrogated. From then on, with alacrity, the Turkish State has made the use of NATO bases conditional upon its own political will. Barring NATO or bilateral relations with the US, the short tenure of IRBMs in Turkey remains an anomaly, but historically, no more or less of an anomaly than the Cold War itself.

\section{NOTES}

This study was conducted by a grant from the Nuclear History Program (University of Maryland - Stiftung Wissenschaft und Politik - Ebenhausen).

1. Latest systematic research was carried out under the auspices of the Nuclear History Project (University of Maryland - Stiftung Wissenschaft und Politik, Ebenhausen) and the Cold War International History Project (Woodrow Wilson International Center for Scholars) with major contributions from American, German, French, Dutch, Italian and Russian scholars.

2. Philip Brenner and James G. Blight, 'The Crisis and Cuban-Soviet Relations: Fidel Castro's Secret 1968 Speech', Cold War International History Project Bulletin 5 (Spring 1995) pp. $81-5$.

3. Philip Nash, 'Nuisance of Decision-Jupiter Missiles and the Cuban Missile Crisis', Journal of Strategic Studies 14/1 (March 1991) pp.2-6.

4. For a comprehensive treatment of the subject, see Michael R. Beschloss, The Crisis Years: Kennedy and Khrushchev, 1960-1963 (NY: HarperCollins 1991).

5. Treaties and Other International Act Series 4191, 'Cooperation: Agreement Between the United States of America and Turkey, March 5, 1959' (Washington DC: US Dept of State/Government Printing Office 1959)

6. A List of Treaties and Other International Agreements of the US in Force On January 1, 1992 (Washington DC: US Dept of State, Office of the Legal Advisor 1992) p.244.

7. Phil Nash, 'Trying to Dump Them On Our Allies: The Search For Hosts 1957 1959', Courtesy of the author (unpub. chapter in dissertation).

8. Yuiksel İnan, ' 1961 Anayasası ve Milletlerarası Andlaşmalar' (The 1961 Constitution and International Agreements) Ankara Iktisadi ve Ticari Illimler Akademisi Dergisi Ill/2 (1971), pp.271-84; M. Piri, 'Dünkü Dış Politika Tutumuna Bakış' Cumhuriyet 2 June 1960, p.3. 
9. Sezai Orkunt, Türkiye-ABD Askeri Illişkileri (Turkish-US Military Relations) (İstanbul: Milliyet Yayınlan, 1978), pp.301-58.

10. David J. Potter and Gregory J. Stachelczyk, 'The Military Relationship Between the United States and Turkey Since 1947', (unpub. MA: thesis, Wright, Patterson AFB, Ohio, Air University: June 1981) p.14; George McGhee, ABD-Türkiye-NATO-Ortadoğu transl. Belkıs Çorakçı (Ankara: Bilgi Yayınevi, 1992) p.275.

11. TBMM Zabit Ceridesi (Minutes of the Turkish GNA Meeting) 4/87 (21 Aug. 1958) pp.850-5.

12. Semih Günver, Fatin Rüşı̈̈ Zorlu'nun Öyküsü (The Story of Fatin Rüştü Zorlu) (Ankara: Bilgi Yayınevi 1985).

13. Interview with Ret. Admiral Sezai Orkunt, June 1992, İstanbul.

14. 'Memorandum for Mr McGeorge Bundy-Subject: Jupiters in Italy and Turkey' in James Grimwood and Frances Strowd (eds.) 'History of the Jupiter Missile System' (US Army Ordnance Missile Command 1962).

15. Ibid.

16. US National Archives [hereafter USNA] Dept of State. RG 59 Box 3742 No.782.54/4-1756, 17 April 1956 Kohler to Sec. of State.

17. DDRS, IV: 2 (1978), President Eisenhower to Gen. Lauris Nostad, SACEUR, 11 July 1957.

18. USNA Dept of State. RG 59 Box 3740, No.782.5/9-2258, NEA to Acting Sec., 22 Sept. 1958.

19. DDRS X: 4 (1984) Christian Herter, Secretary of State to President, 27 April 1959.

20. US National Security Archive [hereafter USNSA]. 1955-1959 Dec.File Box 3160, No.740: 5/5-2059, 'Coordinating Meeting of the US Element Standing Group', 20 May 1959.

21. USNA Dept of State. RG 59, Box 3743, No.782.5-MSP/5-2959, Paris to Sec. of State, 29 May 1959.

22. USNA Dec. File Box 3160, No.740.5/6-259, 'Coordinating Meeting of the US Element Standing Group', 2 June 1959.

23. Courtesy of H.E. Raymond Garthoff, 'Memorandum of Conference with the President', 17 June 1959, by A.J. Goodpaster, Brig. Gen., USA (The Dwight D. Eisenhower Library).

24. Idem. 'Memorandum for the President' from Christian A. Herter, US Dept of State, 16 Sept. 1959.

25. Idem. Dept of State Memo to US Embassy Ankara/Paris/Athens', 17 Sept. 1959.

26. Jan Melissen, 'Nuclearizing NATO, 1957-1959: the "Anglo-Saxons" nuclear-sharing and the fourth country problem', Review of International Studies 20/3 (3 July 1994) pp.253-75.

27. USNA. Dec File Box 3162 No.740.5/11-459 to Hon. Frederich E. Nolting Jr, Acting Chief of Mission, USRO from John Haskell, 'European Production of Medium Range Ballistic Missiles (IRBMs)' 3 Nov. 1959.

28. 'Rusya İzahat İstedi' (Russia asked for an Explanantion) Cumhuriyet, 1 May 1959, pp.1-5.

29. 'Soviet Declaration on Establishing an Atomic Free Zone in the Balkans, June 25, 1959' Documents On American Foreign Relations 1959 (NY: Harper and Bros 1960) p.355.

30. 'Türkiye'de Kurulacak Füze Rampalanna Dair Anlaşma' (Agreement on Building of Rocket Sites in Turkey) Cumhuriyet, 15 Oct.1959, pp.1-5.

31. 'Türkiye'de Kurulacak Füze Üssüne Dair Bir Amerikan Açıklaması' (An American Statement About Rocket Bases that are to be Established in Turkey) Cumhuriyet, 31 Oct. 1959, p.1.

32. Hearings on Military Posture, Committee on Armed Services, House of Representatives, 88th Congress 1st Session Jan./Feb. 1963, p.279 ‘Joint Committee on Atomic Energy Report, $11 \mathrm{Feb} .1961$.

33. Office of the Commander, HQ Mobile Air Material Area 'SM-78 (Jupiter) Weapon Support System Management Division Report', Historical Archives, USNSA.

34. Pierre Salinger, With Kennedy (NY: Doubleday 1966) pp.175-6; Barton J. Bernstein, 'The Cuban Missile Crisis: Trading the Jupiters in Turkey?' Political Science Quarterly 95/1 (Spring 1980) pp.97-125.

35. Khrushchev Remembers-The Glasnost Tapes (transl. and ed.) Jerrold I. Schecter and Vyacheslav V. Luchkov (Boston: Little, Brown 1990) p.179.

36. Raymond Garthoff, From a Presentation at L'Institut de France à Paris, 16-17 Oct. 1992 (GREFHAN-NHP). 
37. USNA, Dept of State RG 59, Box 3743, No.782.54/5-2557 Warren to Sec. of State, 25 May 1957.

38. Idem. Box 3742 No.782.5 MSP/6-658 Fletcher Warren to Sec. of State, 6 June 1958. Subj: FY 1960 Military Aid Proposals.

39. Ibid. MSP/I-1558 İstanbul to Sec. of State, 16 Jan. 1958.

40. T.B.M.M. Zabit Ceridesi Vol.IV: (Records of the Turkish Grand National Assembly Meeting) 21 Aug. 1958, Speech delivered by the Minister of Finance, Hasan Polatkan, p.856.

41. USNA, Dept of State, RG 59, Box 3742, No.782.5-MSP/5-2959 Paris to Sec. of State, 29 May 1959.

42. Ibid. No.782.5-MSP/3-1959, 11 March 1959.

43. Ibid. 'Memorandum of Conversation', 4 Feb. 1959 No. Illegible; 'Amerika'nun Bize Vereceği Füzeler' (Rockets To Be Delivered From America), Cumhuriyet, 24 Jan. 1959, p.3.

44. 'Türkiye'de Kurulacak Güdümlü Mermi Üsleri' (Guided Weaponry Bases To Be Established In Turkey) Cumhuriyet, 5 April 1959, pp.1-5; 'Türkiye'de Füze Üssü Kurulacak' (A Rocket Base Will Be Established In Turkey) Zafer, 5 April 1959, pp.1-4.

45. 'Rusya İzahat İstedi' (Russia Asked For An Explanation) Cumhuriyet ibid.

46. 'Türkiye'nin Yegâne Arzusu Dünyada Sulhun İdamesidir' (Turkey's Only Desire Is That World Peace Continues) Zafer, 15 July 1959, p.1.

47. USNSA. Dec File Box 3162, n.n. Dept of State to US Embassy, Ankara, 17 Sept. 1959.

48. Ibid.

49. 'Dışişleri Komisyonunda Dünkü Mühim Tartışmalar' (Significant Debate in the Foreign Affairs Committee), Cumhuriyet, 6 Feb. 1960, pp.1-5.

50. Fahir Armaoğlu (Comp.) Belgelerle Türk-Amerikan Münasebetleri (Documents on TurkishAmerican Rèlations) (Ankara: Türk Tarih Kurumu Basýmevi 1991) pp.261-2; Oral Sander, Türk-Amerikan İlişkileri, 1947-1964 (Turkish-American Relations, 1947-1964) (Ankara: Sevinç Matbaası 1979) pp.190-6.

51. Hulusi Turgut, 'Türkeş'in Anıları: Fırtınalı Yıllar' (Memoirs of Türkeş) Sabah, 23 June 1994, p.13.

52. Jacob Neufeld, Ballistic Missiles in the United States Air Force 1945-1960 (Washington DC: Office of Air Force History, USAF 1989) p.227.

53. McGhee, $A B D$-Türkiye (note 10).

54. USNSA, Cuban Misile Crisis Box, Dean Rusk to James G. Blight, 25 Feb. 1987.

55. Idem. 'Memorandum, Mr George Bundy', 22 June 1961.

56. Ibid. K-DIV-7217-HI.

57. Metin Toker, 'Haydi Canìm Sen de!' (Come on!) Akis 3 Nov. 1962, p.9; For a comprehensive study of the era, see Michael R. Bechloss, Crisis Years (note 4) pp.546-7.

58. Andrei Gromyko, Memories, transl. Harold Shukman (London: Arrow Books 1989) p.230.

59. Courtesy of HE Raymond Garthoff, Dept of State Telegram Paris to Sec. of State, 29 Oct. 1962.

60. 'Dünyada Olup Bitenler, Küba' (World Affairs, Cuba) Akis, 27 Oct.1962, p.10.

61. Leopoldo Nuti, 'L'Italie et les missiles Jupiter,' in Maurice Vaisse (ed.) L'Europe et la Crise de Cuba (Paris: Armand Colin 1993) pp.123-57.

62. Marc Trachtenberg, 'White House Tapes and Minutes of the Cuban Missile Crisis: Excom Meetings, October 1962', International Security 10/1 (Summer 1985) p.198.

63. Ibid. p.199.

64. Interview with HE Osman Olcay (Ret.), June 1993, Ankara.

65. Robert A. Divine, 'Alive and well: The Continuing Cuban Missile Crisis Controversy', Diplomatic History 18/ 4 (1994) pp. 551-60.

66. Criss, 'Les retombées de la Crise de Cuba: les Jupiters 'turcs' in L'Europe et la Crise de Cuba (note 61) pp.159-68.

67. Richard F. Grimmett, 'United States Military Installations in Turkey', Report No. 84-221F, The US Congressional Research Service (US Library of Congress, 12 Dec. 1984). 